\title{
PERAN PEREMPUAN DALAM KELUARGA
}

\author{
Siti Zahrok ${ }^{1}$, Ni Wayan Suarmini ${ }^{2}$ \\ UPT PMK Sosial Humaniora, FBMT, Institut Teknologi Sepuluh Nopember \\ Email: zahrokits@gmail.com, mini.wayan@gmail.com
}

\begin{abstract}
ABSTRAK
Di zaman era globalisasi ini kesempatan terbuka lebar bagi warga negara untuk memperoleh kesempatan yang sama dalam segala bidang, baik itu kaum laki-laki maupun kaum perempuan' Jumlah kaum perempuan khususnya di Indonesia lebih banyak daripada jumlah kaum laki-laki dari total penduduk. Dengan jumlah perempuan yang demikian besar maka potensi perempuan perlu lebih diperhatikan dan diberdayakan sebagai pelaku untuk berkonstribusi dalam pembangunan bangsa kita. Perempuan sebagai hamba Allah yang lemah, memiliki peran amat besar dalam kehidupan bermasyarakat dan bernegara. Tanpanya kehidupan tidak akan berjalan semestinya. Sebab perempuan adalah pencetak generasi baru. Apabila di muka bumi ini hanya dihuni oleh kaum laki-laki saja kehidupan mungkin sdh terhenti beribu-ribu abad yang lalu. Oleh sebab itu, perempuan tidak bias diremehkan dan diabaikan karena dibalik semua keberhasilan dan kontinuitas kehidupan di situ ada perempuan.. Peranan perempuan dalam keluarga sangat penting. Perempuan merupakan banteng utama dalam keluarga. Peningkatan kualitas sumber daya manusia dimulai dari peran perempuan dalam memberikan pendidikan kepada anaknya sebagai generasi penerus bangsa. Keluarga merupakan awal pendidikan dasar. Dengan demikian jika dikelompok terkecil (keluarga) sudah bagus nanti akan merambah ke lingkungan masyarakat dan bangsa.
\end{abstract}

Kata kunci: era globalisasi, potensi perempuan, peran perempuan, keluarga

\section{PENDAHULUAN}

Di zaman era globalisasi ini kesempatan terbuka lebar bagi warga negara untuk memperoleh kesempatan yang sama dalam segala bidang, baik itu kaum laki-laki maupun kaum perempuan.Jumlah kaum perempuan yang demikian besar, maka potensi perempuan perlu lebih diperhatikan dan diberdayakan sebagai pelaku untuk berkonstribusi dalam pembangunan bangsa kita. Perempuan dan laki-laki memiliki peran dan kedudukan yang setara di dalam mencapai tujuan negara serta di dalam memperjuangkan kesejahteraan di semua bidang pembangunan.

Negara tidak mungkin sejahtera jika para perempuannya dibiarkan tertinggal, tersisihkan, dan tertindas. Seperti yang diungkaplkan oleh Vivekananda (M.Muhajir, 2005). bahwa negara dan bangsa yang tidak menghormati kaum perempuannya tidak akan pernah menjadi besar, baik di saat ini maupun di masa depan. Di samping itu, peran perempuan juga telah diakomodir oleh segenap peraturan pembangunan nasional, seperti UU No. 6 tahun 2014 tentang desa, yang memuat keterlibatan perempuan yang sangat diperlukan bagi keberhasilan pembangunan desa. Peranan perempuan dalam pembangunan masyarakat, baik di perkotaan maupun di pedesaan perlu terus ditingkatkan terutama dalam menangani berbagai masalah sosial ekonomi yang diarahkan pada pemerataan hasil pembangunan, pengembangan sumberdaya manusia yang berkualitas dan pemeliharaan lingkungan (Indonesia, 2014).

Sepanjang sejarah peradapan manusia, besarnya peranan perempuan diawali dengan melahirkan, merawat, serta membesarkan generasi-generasi penerus bangsa yang unggul, semangat, aktif, kreatif, bermoral kemanusiaan, dan penuh inisiatif. Peran ibu sangat besar dalam mewujudkan kebahagiaan dan keutuhan keluarga. Mereka memang disiapkan oleh Allah untuk tugas mendidik 
generasi-generasi baru, baik secara fisik maupun mental. Allah melatihnya sejak ia mengandung seperti rasa sakit, lemah, mual-mual, pusing atau berbagai keinginan aneh. Kemudian harus membawa janinnya kemana saja ia pergi. Latihan yang terbesar adalah saat melahirkan, ia mempertaruhkan nyawa antara hidup dan mati. Eksistensi perempuan telah mendapat pengakuan dari pemerintah baik sebagai warga negara maupun sebagai sumberdaya insan pembangunan. (Pudjiwati, 1993), upaya menyertakan perempuan dalam proses pembangunan bukan hanya merupakan hal yang bersifat manusiawi tetapi juga merupakan tintakan yang efisien.

\section{FUNGSI KELUARGA}

Keluarga merupakan bagian yang tidak dapat terpisahkan dalam kehidupan. Keluarga menjadi tempat pertama seseorang memulai kehidupannya. Keluarga membentuk suatu hubungan yang sangat erat antara ayah,ibu, maupun anak. Hubungan tersebut terjadi antaranggota keluarga yang saling berinteraksi. Keluarga sebagai institusi sosial terkecil yang merupakan fondasi dan investasi awal untuk membangun kehidupan sosial dan kehidupan bermasyarakat secara luas menjadi lebih baik. Hal ini disebabkan karena di dalam keluarga internalisasi nilai-nilai dan norma-norma sosial jauh lebih efektif dilakukan daripada melalui institusi lainnya di luar lembaga keluarga. Peran aktif orang tua terhadap perkembangan anak sangat diperlukan terutama pada saat mereka masih berada di bawah usia lima tahun.

Keluarga memiliki peranan penting dalam menanamkan pola tingkah laku dalam hidup bermasyarakat. Hal ini dilakukan dengan menanamkan nilai-nilai yang baik dalam diri anak tersebut, menanamkan nilai dan norma sesuai dengan tingkah laku, usia, dan mewariskan nilai-nilai budaya keluarga. Di samping itu, dalam keluarga akan diberikan rasa cinta dan kasih sayang, rasa aman, serta diberikan perhatian diantara anggota keluarga. Keluarga dapat memunculkan suasana aman, nyaman, adil, dan terlindungi. Keluarga adalah tempat mengadu semua masalah yang dilakukan oleh anggota keluarganya.

Menurut Badan Koordinasi Keluarga Berencana Nasional /BKKBN (1992), keluarga mempunyai fungsi agama, sosial budaya, cinta dan kasih sayang, perlindungan, reproduksi, sosialisasi dan pendidikan, ekonomi, dan fungsi lingkungan (Hikmatuz Zoleha Sayyong, 2012).

Fungsi pertama yang terdapat dalam keluarga adalah fungsi agama. Di dalam keluarga, kita dikenalkan dan diajarkan tentang keberadaan Tuhan yang maha Esa dan diajarkan cara beribadah yang benar. Disamping itu, dalam keluarga ditanamkan nilai-nilai agama dan sekaligus memberikan identitas agama kepada anak. Apabila di dalam menerapkan nilai-nilai agama dalam kehidupan sehari-hari berhasil maka dapat dikatakan mampu memberikan fondasi yang kuat bagi setiap anggota keluarganya. Fungsi cinta dan kasih sayang mengharuskan keluarga menjadi tempat untuk menciptakan suasana cinta dan kasih sayang dalam kehidupan berkeluarga, bermasyarakat, berbangsa dan bernegara. Dalam kehidupan keluarga, cinta kasih dan kasih sayang antara anggota keluarga akan dapat menumbuhkan rasa tanggung jawab terhadap keharmonisan keluarga tersebut. Dengan demikian, setiap anggota keluarga akan selalu menjaga komitmen yang telah dibuat bersama. Maka dari itu, dalam kehidupan bermasyarakat dengan fungsi ini i juga akan menimbulkan keharmonisan dalam bermasyarakat.

Fungsi sosial budaya dalam keluarga mengajarkan bagaimana kita bersosialisasi dengan orang lain dan bagaimana cara kita menghargainya. Kita pribadi tidak bisa hidup tanpa orang lain karena kita butuh orang lain untuk bersosialisasi. Fungsi perlindungan dalam keluarga adalah melindungi anak dan 
keluarganya dari tindakan-tindakan yang tidak baik sehingga anggota keluarganya merasa aman dan terlindungi.

\section{PERAN IBU DALAM KELUARGA}

Ibu merupakan sosok yang tidak bisa dihilangkan dalam sebuah keluarga. Peran aktif orang tua merupakan sebuah usaha yang secara langsung dalam memberikan sosialisasi terhadap anak dan juga menciptakan lingkungan. Rumah sebagai lingkungan sosial pertama yang dijumpai oleh anak. Keluarga merupakan tempat pertama anak dilahirkan di dunia dan menjadi tempat bagaimana anak belajar dalam berkehidupan, yaitu dari awal cara makan sampai anak belajar hidup dalam masyarakat.. Keluarga menjadi hal yang sangat penting dan membawa anak untuk menjadi seorang individu yang baik. Keluarga merupakan pusat pendidikan yang pertama dan terpenting.

Keluarga sangat berpengaruh besar terhadap perkembangan anak. Peranan orang tua bagi pendidikan anak adalah memberikan dasar pendidikan, sikap, dan keterampilan dasar seperti budi pekerti, sopan santun, estetika, kasih sayang, rasa aman, dasar-dasar mematuhi peraturan dan menanamkan kebiasan- kebiasaan yang baik. Pentingnya peranan orang tua dalam pendidikan anak telah disadari oleh banyak pihak. Mengasuh, membina, dan mendidik anak di rumah merupakan kewajiban bagi setiap orang tua dalam usaha membentuk pribadi anak. Sosialisasi menjadi sangat penting dalam pembentukan kepribadian anak. Lewat sosialisasi yang baik, anak merasa diperhatikan oleh orang tuanya sehingga dia mempunyai suatu motivasi dalam membentuk kepribadian yang baik. Keluarga sangat berpengaruh besar terhadap sosialisasi anak.

Ibu merupakan sosok utama yang memegang peranan penting dalam sebuah keluarga. Ibu memiliki banyak peranan dan mampu melakukan banyak hal untuk kebutuhan semua anggota keluarga. Ibu adalah sosok seorang super women yang mampu melakukan banyak hal termasuk memasak, mengasuh anak, mendidik, menata rumah, dan banyak hal lainnya. Begitu banyaknya peran Ibu tidak bisa dideskripsikan seberapa hebat sosok seorang lbu tersebut. Seorang Ibu juga memberikan keseimbangan dalam sebuah keluarga. Kedudukan perempuan dalam kelurga dan masyarakat perlu dipelihara dan ditingkatkan sehingga dapat memberikan sumbangan yang sebesar-besarnya bagi pembngunan bangsa dengan memperhatikan kodrat serta harkat dan martabat (Achmad, 1994).

Peran penting ibu dalam keluarga adalah Ibu sebagai Seorang Manajer Keluarga, Ibu sebagai Seorang Pendidik, Ibu sebagai Seorang Psikolog bagi Anak dan Keluarga, Ibu sebagai Perawat, Ibu sebagai Seorang Koki, Ibu sebagai Pelindung, Ibu sebagai Panutan, Ibu sebagai Akuntan Keluarga, Ibu sebagai Motivator Keluarga, Ibu sebagai Dokter Keluarga, Ibu sebagai Fashion Ddesigner, Ibu sebagai Interior Designer, Ibu sebagai Sekretaris, Ibu sebagai Ahli Perbaikan, Ibu sebagai Sahabat, Ibu sebagai Event Organizer, Ibu sebagai Pegawai Tauladan, Ibu sebagai Penjaga Kebersihan, Ibu sebagai Partner, Ibu sebagai Superhero (dosenpsikologi.com, 2017).

Peran ibu sebagai seorang manajer keluarga adalah Ibu memiliki wewenang dalam semua hal yang terjadi dalam keluarga. Dalam hal ini ibu juga bertugas menyatukan anggota keluarga dan menyelesaikan masalah yang ada, serta mengatur segala kebutuhan perencanaan, penyelesaian masalah keuangan dan sebagainya. Masalah keluar masuknya uang menjadi tanggung jawab ibu. Oleh karena itu, ibu harus bisa mengendalikan keuangan keluarga. Di samping itu, Ibu sebagai seorang pendidik. Pendidikan yang dimaksud adalah apa yang diajarkan oleh seorang Ibu kepada anaknya. Ibu sebagai sekolah pertama bagi anak karena pendidikan anak dimulai di dalam keluarga. Dari ibulah seorang anak belajar mengenal segala hal baru dalam hidupnya. Anak mulai belajar berbicara, makan, minum, bergaul, atau bersosialisasi dengan ibu. Ibu juga paling mengerti karakter anak sehingga mampu memberikan 
pendidikan yang sesuai. Di samping itu, Ibu sebagai pilar utama dalam proses pendidikan bagi anaknya. Prestasi dan kesuksesan anak sangat berkaitan erat dengan peran ibu sebagai sekolah pertama bagi anaknya. Peran ibu yang lain adalah sebagai psikolog bagi anak dan keluarganya. Ibu menjadi psikolog yang memperhatikan tumbuh kembangnya anggota keluarganya mulai dari tumbuh kembang kejiwaan karakteristik, perilaku yang dilakukan oleh setiap anggota keluarganya. Ibu dapat dijadikan tempat mencurahkan keluh kesah bagi anak. Ibulah yang seharusnya memberikan rasa aman bagi anak-anaknya.

Peran ibu sebagai perawat merupakan sosok yang paling peduli tentang kesehatan anggota keluarganya. Ibu selalu memberikan yang terbaik untuk menjaga kesehatan keluarganya. Ibu memberikan nutrisi yang cukup agar anggota keluarganya tidak jatuh sakit. Ibu selalu berusaha agar anaknya selalu bisa hidup sehat dan bahagia. Peran Ibu selanjutnya sebagai seorang koki. Ibu berperan menghidangkan makanan yang enak dan sehat untuk keluarga setiap hari. Ibu yang harus memilihkan makanan yang cocok untuk keluarganya. Ibu ibaratnya sebagai seorang koki atau chef yang harus bisa sekreatif mungkin ketika sedang memasak di dapur. Ibu akan memutar otaknya untuk memasak menu yang enak, lezat, dan bergizi, untuk para anggota keluarganya. Mulai dari sarapan, makan siang, hingga makan malam, semua dimasak oleh ibu dengan penuh rasa cinta agar gizi anggota keluarganya selalu terpenuhi. Peran Ibu sebagai pelindung. Ibu sebagai pelindung baik secara fisik maupun mental dan emosional. Ibu sebagai pelindung mental dan emosi siap mendengarkan cerita kehidupan tiap anggota keluarganya dan memberikan masukan positif yang selalu berisi dukungan dan nasehat. Ibu selalu melindungi anak dari tindakan-tindakan yang tidak baik sehingga anak merasa aman dan terlindungi.

Peran Ibu yang lain adalah sebagai panutan. Ibu merupakan sosok panutan yang selalu kuat. Ibu juga menanamkan nilai-nilai keagamaan dan nilai kemanusiaan pada anak. Sosok lbu yang baik memberikan panutan yang positif pada anak untuk meniru perbuatan baik tersebut. Peran Ibu dalam keluarga juga sebagai akuntan keluarga, sebagai motivator keluarga, sebagai dokter keluarga, sebagai fashion designer, sebagai interior designer, sebagai sekretaris, sebagai ahli perbaikan, sebagai sahabat, sebagai event organizer, sebagai pegawai tauladan, sebagai penjaga kebersihan, sebagai partner, dan sebagai superhero. Peran sebagai akuntan adalah Ibu mengatur semua pemasukan dan pengeluaran dalam rumah tangga. Sedangkan peran sebagai motivator keluarga, Ibu selalu memberikan dukungan pada setiap anggota keluarganya selama hal tersebut dinilai positif. Peran sebagai dokter keluarga, Ibu selalu mengetahui tanda-tanda anggota keluarganya yang akan sakit. Ibu akan memberikan obat yang terbaik untuk anggota keluarganya. Ibu sebagai fashion designer memperhatikan tentang apa yang sedang dikenakan oleh semua anggota keluarganya. Ibu memperhatikan pakaian yang dipakai oleh anak dan suaminya sudah sesuai atau sudah cukup bersih. Di samping itu, Ibu juga mampu mengatur pembagian ruangan rumah, tata letak interior yang sesuai. Ibu juga mengenal dengan baik kebutuhan dalam rumah tangga dan kebutuhan setiap anggota keluarganya yg disebut sebagai sekretaris keluarga. Selanjutnya peran Ibu sebagai ahli perbaikan dan sebagai sahabat adalah Ibu seorang perempuan yang bisa melakukan banyak hal yang seharusnya dilakukan oleh laki-laki. Ibu bisa memperbaiki berbagai macam barang rusak atau menemukan solusi untuk perawatan perabotan rumah tangga.Ibu juga bisa mendengarkan dengan baik keluhan atau curhatan dan memberikan masukan yang positif yang membangun. Hal tersebut mencerminkan Ibu berperan sebagai sahabat.

Peran Ibu sebagai event organizer adalah Ibu mampu menangani jenis acara keluarga baik acara resmi maupun acara jalan-jalan. Sedangkan Ibu sebagai pegawai teladan adalah Ibu merupakan sosok yang bisa menangani banyak hal secara bersamaan. Ibu sebagai penjaga kebersihan adalah Ibu mengawasi setiap sudut rumah dan tingkah laku anggota keluarganya yang tidak menjaga kebersihan. Peran Ibu sebagai parner dan sebagai superhero adalah Ibu sebagai partner dari ayah yang kompak untuk segala keputusan yang terkait dengan anak, keluarga,rumah dan lainnya. Peran Ibu yang terakhir adalah sebagai superhero. Ibu mempunyai segala macam kemampuan yang dimiliki sehingga menjadikannya seorang superhero. Ibu adalah wanita super yang berjuang untuk keluarganya. 


\section{DAFTAR PUSTAKA}

Achmad, S. (1994). Peningkatan Peranan Wanita dalam Pembangunan. jakarta: Kantor Menteri UPWRI.

dosenpsikologi.com. (2017). 20 Peran Ibu dalam Keluarga Menurut Psikologi. Retrieved July 10, 2018, from https://dosenpsikologi.com/peran-ibu-dalam-keluarga

Fungsi keluarga menurut BKKBN (1992). (n.d.). Retrieved from https://www.scribd.com/doc/78815992/Fungsi-Keluarga-Menurut-BKKBN

Hikmatuz Zoleha Sayyong. (2012). Fungsi Keluarga Menurut BKKBN. Retrieved July 20, 2018, from https://www.scribd.com/doc/78815992/Fungsi-Keluarga-Menurut-BKKBN

Indonesia, R. UNDANG-UNDANG REPUBLIK INDONESIA NOMOR 6 TAHUN 2014 TENTANG DESA, Pub. L. No. NOMOR 6 TAHUN 2014 TENTANG DESA (2014). Indonesia. Retrieved from http://www.dpr.go.id/dokjdih/document/uu/UU_2014_6.pdf

M.Muhajir, D. (2005). Negara dan Perempuan. Yogyakarta: Media Wacana.

Pudjiwati, S. (1993). Peranan Wanita dan Pembangunan Masyarakat Desa. Jakarta: Kanisius. 